\title{
Palaeozoic insect nymphs: new finds from the Piesberg quarry (Upper Carboniferous, Germany)
}

\author{
JoACHIM T. HAUG, ANGELIKA LEIPNER, TORSTEN WAPPLER \& CAROLIN HAUG
}

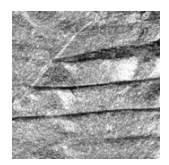

\begin{abstract}
We report fragmentary specimens from the Piesberg quarry (Upper Carboniferous, Northwestern Germany) that represent exuviae of nymphal blattoids (Dictyoptera). Most of the remains are isolated abdomina, one specimen also preserves a wing pad. The specimens document two developmental stages and include the smallest Palaeozoic blattoid nymph found to date. The specimens from the Piesberg quarry closely resemble other Palaeozoic blattoid nymphs, for example, specimens from the famous Mazon Creek Lagerstätte (Upper Carboniferous, Illinois, USA), at least as far as external morphology is concerned. As for preservation, the specimens from the Piesberg quarry show strong resemblance to specimens from the Lower Permian Elmo Lagerstätte (Kansas and Oklahoma, USA). The two Lagerstätten, although differing in age, appear therefore to be interesting candidates for a palaeoecological comparison. The find of immature insects at the Piesberg quarry is another example of fossilised development in arthropods from this Lagerstätte, other examples are known from Euproops, Arthropleura and Aphantomartus pustulatus. - Key words: Dictyoptera, nymph, hemimetaboly, blattoid, palaeo-evo-devo.
\end{abstract}

Haug, J.T., Leipner, A., Wappler, T. \& Haug, C. 2013. Palaeozoic insect nymphs: new finds from the Piesberg quarry (Upper Carboniferous, Germany). Bulletin of Geosciences 88(4), 779-791 (5 figures). Czech Geological Survey, Prague. ISSN 1214-1119. Manuscript received December 7, 2012; accepted in revised form June 17, 2013; published online September 11, 2013; issued October 31, 2013.

Joachim T. Haug (corresponding author) \& Carolin Haug, University of Greifswald, Zoological Institute and Museum, Department Cytology and Evolutionary Biology, Soldmannstrasse 23, 17487 Greifswald, Germany; joachim.haug@palaeo-evo-devo.info • Angelika Leipner, Museum am Schölerberg, Klaus-Strick-Weg 10, 49082 Osnabrück, Germany• Torsten Wappler, University of Bonn, Steinmann Institute, Nussallee 8, 53115 Bonn, Germany

Although Arthropoda is commonly considered the largest animal group, it can be argued that it is a matter of scale and of point of view (Arthropoda and its sister-group is larger than Arthropoda). However, regardless of these aspects, it is generally admitted that Arthropoda compose a very successful lineage. The early evolution of Arthropoda sensu stricto, the sclerotized arthropods (Waloszek et al. 2005), has been deduced mainly from Cambrian arthropod fossils (e.g., Maas et al. 2004; Waloszek et al. 2005, 2007; Scholtz \& Edgecombe 2006; Budd 2008). Also younger fossil deposits have provided fossil specimens that contributed significantly to our understanding of arthropod evolution and diversification. Among these are fossils from younger $\mathrm{Pa}-$ laeozoic strata (e.g., Briggs \& Bartels 2001, Briggs et al. 2005, Kühl et al. 2008, Van Roy et al. 2010), but also from Mesozoic Lagerstätten such as the lithographic limestones of southern Germany (Haug, J.T. et al. 2010).

Especially the Carboniferous has been suggested to be an important period for understanding the evolution of Arthropoda (e.g., Stockmeyer Lofgren et al. 2003). For insects, for example, the Carboniferous is an important time span with a significant fossil record as it is closest to the origin of insects, directly after the huge diversification through which insects became one of the dominant groups of animals on land. Examples of major important Carboniferous Lagerstätten are Mazon Creek and Bear Gulch in North America (e.g., Schram \& Horner 1978, Factor \& Feldmann 1985, Shabica \& Hay 1997, Schram et al. 2006), the coal measures in the United Kingdom (e.g., Bolton 1921-1922), and Montceau-les-Mines in France (e.g., Poplin \& Heyler 1994; Racheboeuf et al. 2002, 2008, 2009).

An important Carboniferous locality is the Piesberg quarry, near Osnabrück in Lower Saxony (Northwest Germany). It has already yielded a large diversity of arthropods. Chelicerates (spiders, scorpions, and close relatives) are represented by the xiphosuran Euproops (Schultka 2000, Haug, C. et al. 2012b), the trigonotarbid Aphantomartus pustulatus (Scudder, 1884) (Rößler 1998), and a single specimen of the scorpion Eoscorpius cf. carbonarius Meek \& Worthen, 1868 (Dunlop et al. 2008). Crustaceans are represented by diplostracans (e.g., Dunlop et al. 2008) and ostracods (Braun 1997). Remains of the giant arthropod Arthropleura have also been discovered 
(Brauckmann \& Herd 2002). Insect remains from the Piesberg are mainly composed of isolated wings and wing fragments representing 21 species (Brauckmann 1983, 1991, 1995; Brauckmann \& Herd 2000, 2002, 2005, 2007; Zessin 2006, 2008; Béthoux \& Herd 2009; Brauckmann et al. 2009). About ten additional species remain to be described (A. Leipner, pers. obs.).

Although fossil arthropod material appears to be not uncommon in the Piesberg quarry, the situation can, at least in part, be compared to that of the famous Rhynie chert Lagerstätte: animal remains are outnumbered by orders of magnitude by those of plants; and the arthropod material is often fragmentary, making it difficult to differentiate from plant debris. In fact, this appears to be a common pattern in many Palaeozoic insect localities. Yet, investigating such incomplete material is important and has, for example, in the case of the Rhynie chert and associated Windyfield chert or Mazon Creek, provided significant information on early freshwater and terrestrial arthropods, including crustaceans, chelicerates, insects, and enigmatic arthropods of unclear affinities (e.g., Hirst 1923; Scourfield 1926, 1940; Shabica \& Hay 1997; Anderson \& Trewin 2003; Fayers \& Trewin 2003, 2005; Dunlop et al. 2004; Haug, C. et al. 2012a). Including fragmentary material into scientific studies is important for several aspects of research, such as the taphonomy of a deposit, the pre-burial history of the fossils, or for understanding biodiversity or ecological interactions of the investigated biota. Furthermore, it can also simply provide formerly unknown morphological features (e.g., Briggs 1979, Anderson \& Trewin 2003, Van Roy \& Tetlie 2006, Daley \& Budd 2010) if at least certain key features are preserved (e.g., Santini \& Tyler 2004).

Herein we report new arthropod material from the Piesberg quarry that represents exuviae of nymphal blattoids. For comparison, we also present material from the famous Upper Carboniferous Mazon Creek Lagerstätte (Illinois, USA) and the Lower Permian Elmo Lagerstätte (Kansas and Oklahoma, USA; e.g., Beckemeyer 2000) that shows astonishing similarities with the new material.

\section{Material and methods}

\section{Material}

The Piesberg quarry comprises Late Carboniferous (Pennsylvanian) strata. For details of the geological settings, see, for example, Dunlop et al. (2008) and Fig. 1.

In total, four arthropod specimens were investigated from the Piesberg quarry. Three of them previously belonged to the collection of Michael Sowiak (Glandorf, Germany), and now belong to the palaeontological collection of the Museum am Schölerberg (MAS Pal) at Osnabrück, just like the fourth specimen. Repository numbers are
MAS Pal 603 and 653-655. Specimens MAS Pal 653 and 655 come from the overlaying claystones of the coal seam Flöz Mittel. The specimen MAS Pal 653 (Fig. 2A, B) is preserved in the typical shale-type-preservation (see below for explanation on preservation types) and was found in October 2009. The specimen MAS Pal 655 (Fig. 3A, B) is covered by a reddish gumbelite layer and was found on 26 April 2008. The specimen MAS Pal 603 (Fig. 4A-D), with a reddish gumbelite layer, was found by one of the authors (AL) in the layers above the coal seam Flöz Zweibänke at 10 July 2011. Specimen MAS Pal 654 (Fig. 4E-I) is composed of part and counterpart. It was found in the overlaying layers of the coal seam Flöz Mittel in June 2008. This specimen is preserved in shale typepreservation, but highly distorted and incomplete.

For comparison, additional material from the deposits of Elmo (Figs 2C-F, 3C, E, 4J, K) and of Mazon Creek (Fig. 3D) was investigated. The specimens are housed in the Invertebrate Palaeontology collection of the Yale Peabody Museum (New Haven, Connecticut, USA; YPM IP).

\section{Types of preservation and methods}

In principle, two types of preservation can be differentiated among the arthropod fossils from the Piesberg quarry. These two types demand different methods for optimal photographic documentation.

Some specimens are preserved in a way similar to shale-type preservation, similar to fossils from the Burgess Shale (concerning the optical properties of the fossil). Such specimens are completely black under crossed polarized light filters, while the matrix is light gray (Figs 2A, 4F, H; $c f$. Bengtson 2000). Under unpolarized reflective light these specimens differ from the matrix because of their reflection qualities, different from those of the matrix (Figs 2B, 4E, G, I; cf. García-Bellido \& Collins 2006). The second preservation type involves a coverage by an irregular film of gumbelite ( $c f$. Brauckmann \& Herd 2002). This mineral has a white or yellowish to reddish appearance. Bluish to greenish colour variations can occur as well. Reflection qualities of such mineral films do not differ from those of the matrix. Still, contrast to the matrix is enhanced by applying crossed polarized light filters (Fig. 3A). Also fluorescence can be used to enhance the contrast against the matrix, as gumbelite exhibits weak, but usable, autofluorescence (Fig. 3B). In detail, this method involves cyan filters placed on light sources, a red filter placed on the lens, and requires very long exposure times ( $c f$. Haug, J.T. et al. 2011a and references therein for further methodological details).

Specimens from Elmo and Mazon Creek were documented under crossed polarized light and dry (i.e., without immersion). Light was provided as shadow-free as possible 


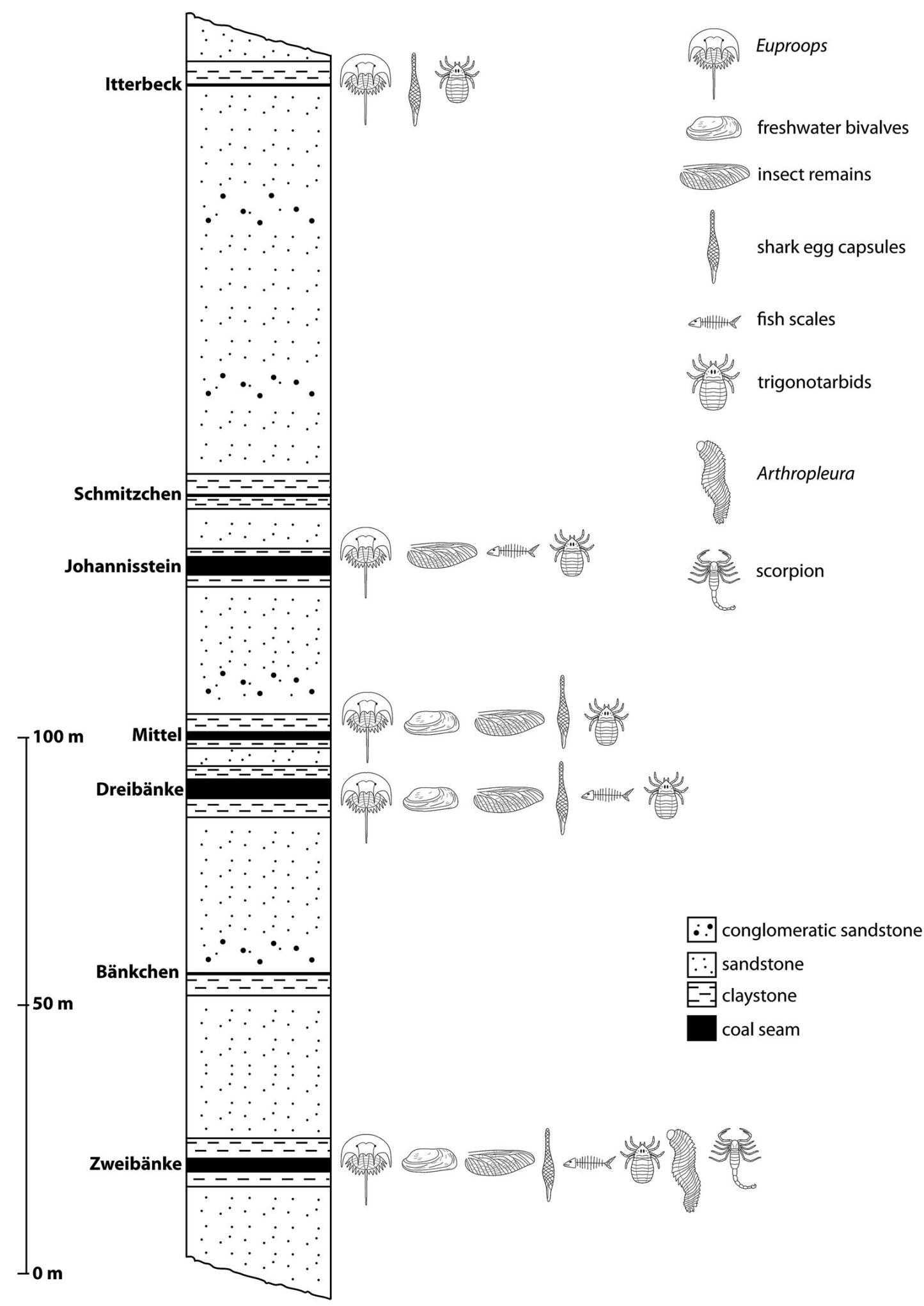

Figure 1. Profile of the Piesberg quarry (modified after Schultka 2000) with faunistic elements. The profile shows only the now exposed layers of the Late Carboniferous (Pennsylvanian) with faunal elements (excluding Foraminifera, Diplostraca, Ostracoda, and undetermined crustaceans). The fossil-rich layers are the claystones in the roof of the coal seams. Here the most interesting faunal elements are found. The clays below the coal seams are autochtonous root clays bearing only fossil roots. From the region of coal seam Zweibänke we know autochtonous stems with roots of lycopods. From the coal seam Mittel we know one autochtonous lycopod stem. In all fauna-bearing layers the plant fossils are dominating. The coal seam Zweibänke is the border between Westphalian C and Westphalian D. 
to avoid possible artefacts through shadows or reflections, and to enhance colour contrast against the matrix.

A 3D model of the Piesberg specimens (Fig. 5A, B) was reconstructed with the open source software Blender. Missing information such as the texture was obtained from extant terrestrial arthropods.

\section{Note on terminology}

We will in the following use the term "abdomen" in the classical insect terminology. Nevertheless, we are aware that this term is used for different structures in different arthropods (e.g., Walossek \& Müller 1998, Hughes \& Kaufman 2002).

\section{Results}

\section{Specimen MAS Pal 653}

Description. - This specimen is the smallest one (Fig. 2A, B). A subrectangular structure antero-laterally partly covers a segmented body region of typical arthropod appearance. Ten segments can be recognised based on their dorsal sclerotisations, the tergites. The anterior-posterior dimensions are about the same in each tergite. The left sides of the anterior four tergites are partly covered by the subrectangular structure; the right sides of these tergites are incompletely preserved. The total width and the lateral shape of these tergites is therefore unknown. The preserved middle parts appear rather straight. Tergite five is also quite straight, but its lateral sides curve backward into a posteriorly pointing tip. These lateral rims appear to be tergo-pleura-like extensions of the tergite. Tergite six resembles tergite five, but is slightly more curved and less wide, in order to fit between the backward curving tergo-pleura-like extensions of tergite five. Tergites seven to nine decrease further in width and are more curved than their predecessor tergite. Tergite ten is only very incompletely preserved.

Remark. - Originally the specimen was interpreted as a more or less complete body fossil of a sclerotised arthropod. In this interpretation, the subrectangular structure was thought to be a displaced head shield, probably due to moulting. Comparable displacement is known, for example, in trilobites. Only the comparison to specimens from Elmo made it clear that this fossil is less complete than originally thought and that the subrectangular structure is not a head shield.

Comparison. - Specimen YPM IP 221025 (Fig. 2C) strongly resembles MAS Pal 653 in general shape, especially in its posterior region. Yet, it is more completely pre- served. Tergite ten has two pronounced notches. Anterior to the parts also seen in MAS Pal 653 another structure is preserved. It appears to consist of two subtrapezoidal substructures connected, but separated by a distinct fold, anteriorly additionally by an incision.

Specimen YPM IP 221045 (Fig. 2D) can also be identified as a comparable specimen although the posterior end is less complete. Yet, it possesses not just one subrectangular structure covering the anterior tergites, but two of these, in the corresponding positions of MAS Pal 653 and YPM IP 221025. They are closely adjacent, but separated. Anteriorly, another pair of subrectangular structures is present, being larger than the posterior ones. The further anterior region is missing in this specimen as the slab is broken here.

Specimens YPM IP 221060 and YPM IP 220994 (Fig. 2E, F) lack the posterior body, but have the posterior pair of subrectangular structures partly and the anterior pair more completely preserved. Apparently connected to the anterior pair is a pair of subtrapezoidal structures on both specimens, resembling the isolated ones in YPM IP 221025 (Fig. 2C).

Interpretation. - The subtrapezoidal and subrectangular structures can be identified as left and right halfs of pro-, meso- and metanotum of a dictyopteran ("roachid") nymph (see taphonomy discussion below). The anterior pair of subtrapezoidal structures in YPM IP 221025 (Fig. 2C) could be identified as two halves of a pronotum from comparison with the anteriorly more completely articulated specimens YPM IP 221060 and YPM IP 220994 (Fig. 2E, F). The ten tergite-bearing segments accordingly represent the abdomen. Specimen MAS Pal 653 is, due to its very similar appearance to YPM IP 221025, also interpreted as a dictyopteran nymph.

\section{Specimen MAS Pal 655}

Description. - This specimen strongly resembles the specimens described before, but only consists of the tergites of the posterior segments (Fig. 3A, B). Assuming a similar number of segments, the preserved tergites represent segments three to ten. This is supported by the fact that in this counting also tergite five is the widest and less curved one of the series. Compared to specimen MAS Pal 653 the specimen is larger and a bit more slender. Segment ten is very well preserved and clearly shows two deep notches.

Comparison. - Specimen YPM IP 210164 (Fig. 3C) resembles specimen MAS Pal 655 in representing also only the posterior trunk region. The notches seen here (but also, e.g., in specimen YPM IP 221025; Fig. 2C) most likely originally bore appendages. This can be seen in specimens from Mazon Creek, e.g., in YPM IP 027869 (Fig. 3D). In 

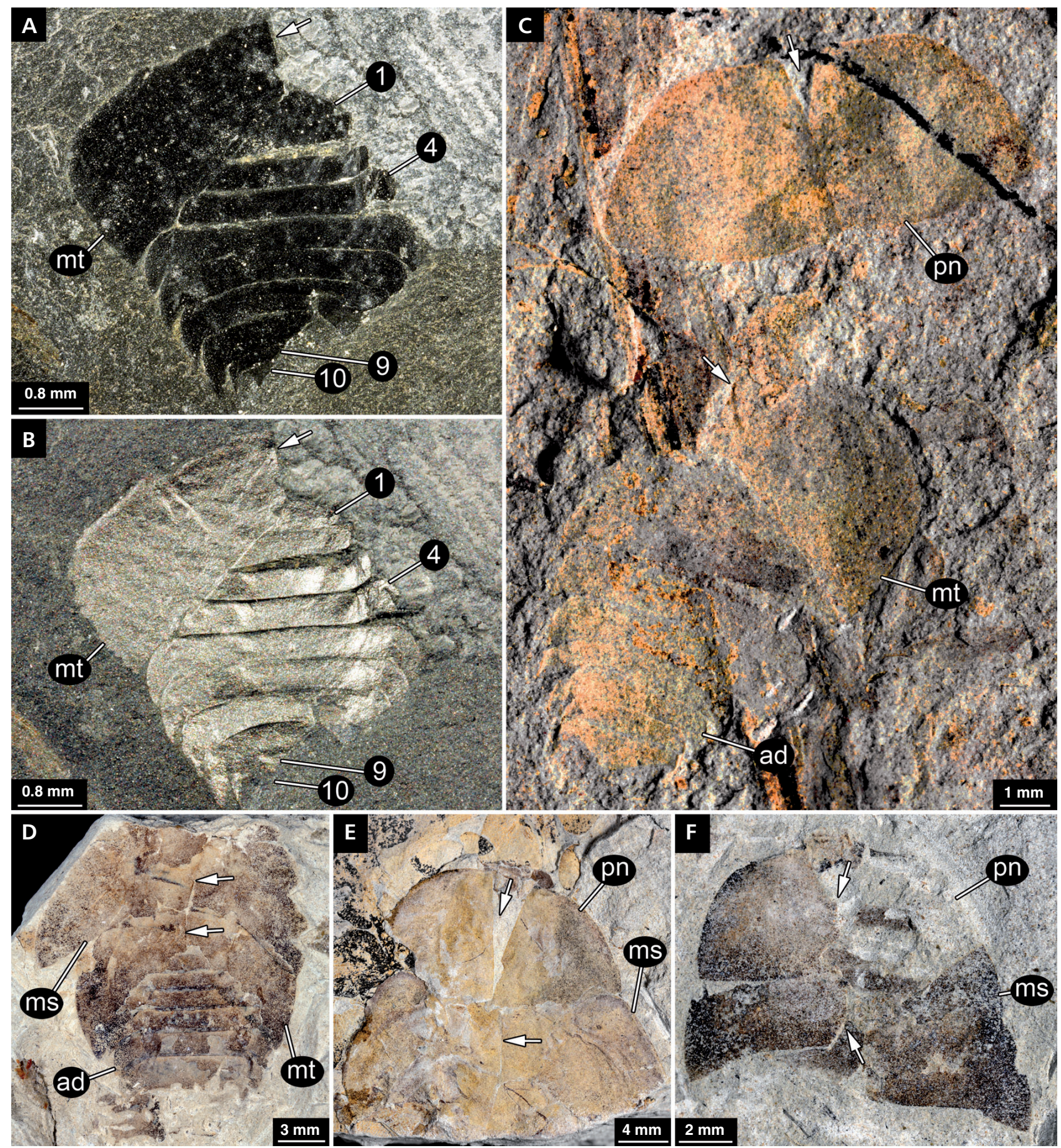

Figure 2. Smaller instar of the blattoid nymphs from the Piesberg quarry and comparative specimens from Elmo. • A, B - MAS Pal 653. Specimen represented by large part of the abdomen with ten segments and the left metanotum, with the right side missing (arrow); A - under polarized light, B - under reflected light. • C-F - similar blattoid nymphs from Elmo; C - YPM IP 221025. Like in A and B, the abdomen and one half of the metanotum (here the right one) is preserved. Additionally, the isolated pronotum lies next to these elements. Pro- and metanotum with distinct line of separation across dorsal midline (arrows). • D - YPM IP 221045. Specimen preserved with abdomen, meso- and metanotum. The latter two with a distinct dorsal line of separation of left and right side (arrows). $\bullet \mathrm{E}, \mathrm{F}$ - fragmentary specimens, complementary to the situation in A and B. Metanotum only partly preserved, abdomen absent. Pro- and mesonotum with distinct line separating left and right side (arrows); E - YPM IP 221060, F - YPM IP 220994. Abbreviations: 1-10 - abdominal segments 1-10; ad - abdomen; ms - mesonotum; $\mathrm{mt}$ - metanotum; pn - pronotum. 
general, an incomplete preservation as in MAS Pal 655 appears not to be uncommon; in fact, fragmentation can become even more pronounced, e.g., specimen YPM IP 221049 represents only one half of a single abdominal tergite with great similarilty to the seventh abdominal segment of MAS Pal 655 (Fig. 3E).

Interpretation. - As a strong resemblance to the previously described specimens is evident, MAS Pal 655 is also interpreted as a fragment of a dictyopteran nymph. Also the notches for the cerci support this interpretation. As MAS Pal 655 differs slightly in size from the co-occurring specimen MAS Pal 653, it could represent an older instar or a different species.

\section{Specimen MAS Pal 603}

Description. - This specimen (Fig. 4A-D) is very similar to MAS Pal 655 (Fig. 3A, B). It also consists only of associated posterior trunk tergites. Due to comparisons with other specimens, these are interpreted as tergites of segments five to ten. Tergite ten, as in other specimens, has two deep notches (Fig. 4C, D). Also size and dimensions of this specimen are similar to MAS Pal 655.

Comparison and interpretation. - As we have also here a strong resemblance to other specimens, MAS Pal 603 is also interpreted as a fragment of a dictyopteran nymph. Due to the similar size to MAS Pal 655, it is interpreted to belong to the same species and/or size class.

\section{Specimen MAS Pal 654}

Description. - This specimen is apparently distorted and folded (Fig. 4E-I). It appears to consist of the abdominal segments two to ten, represented by their tergites. Anteriorly, a structure partly covering the abdominal segments could represent the damaged metanotum. The right side of the abdominal segments appears to be broken (arrows in Fig. 4E), while the left side is folded onto the body. On the left side, also tergo-pleura-like extensions are visible. From segment ten an elongated structure arises (Fig. 4I). This structure appears to have been flexible, tapers distally and is annulated, at least in its proximal region. It is interpreted as an attached cercus. Based on the proximal annulation, a total number of 13 to 15 annuli of the cercus can be estimated.

Comparison. - The preservation of this specimen appears rather unusual. Breakage lines running right through specimens are also found in specimens from Elmo, e.g., YPM IP 221044 (Fig. 4J), and also partial displacement of parts overlapping each other can be seen in this specimen and in YPM IP 220990 (Fig. 4K). Yet, another case of clear folding could not be observed. Remarkable is the presence of a cercus. Cerci have been interpreted to become detached early in the process of fragmentation (Duncan et al. 2003). Thus, attached cerci are usually found in more complete specimens. The high degree of damage and distortion, but the presence of an attached cercus in this specimen might challenge the assumptions about the fragmentation process.

Interpretation. - The general morphology and size of this specimen, despite its distorted nature, is quite similar to that of MAS Pal 655 and MAS Pal 603. The specimen is therefore also interpreted as a dictyopteran nymph belonging to the same species and/or size class as the other two specimens.

\section{Taxonomic remarks and size classes}

To date, no blattoid species has been formally described from the Piesberg quarry, but isolated adult blattoid wings have already been found there (Brauckmann \& Herd 2005, A. Leipner, pers. obs.). Revisions of Palaeozoic blattoids have been presented in a number of contributions by J. Schneider (e.g., Schneider 1983, 1984) who also intends to study the numerous Piesberg specimens in detail. It seems premature to formally describe the specimens presented here as separate new species. Such a description would cause serious problems when the corresponding adult will be described. An ascription of the described nymphs to a specific species will thus be postponed until the material by Sellards has been re-examined (see below), and also until the blattoid wings from the Piesberg quarry are described with some morphological detail (J. Schneider, in prep.).

The four specimens can be separated into two size classes (Fig. 5C). Class I is represented by the specimen MAS Pal 653, and class II is represented by the specimens MAS Pal 654, MAS Pal 655, and MAS Pal 603. Both size classes are morphologically similar, considering the parts that are preserved.

Amending the information on the specimens from the Piesberg quarry by knowledge on the more numerously available specimens from Elmo and Mazon Creek (based on Sellards 1903, 1904a, b), we can reconstruct the principal morphology of the Piesberg blattoid nymphs (Fig. 5A, B). Based on this, we can also estimate the total length of the specimens (Fig. 5C). MAS Pal 653, the smaller specimen, has a reconstructed length between $8-9 \mathrm{~mm}$. The three larger specimens, apparently being all of the same size class, are more difficult to estimate (no wing), but should be up to twice the size. Most of the specimens from Elmo 

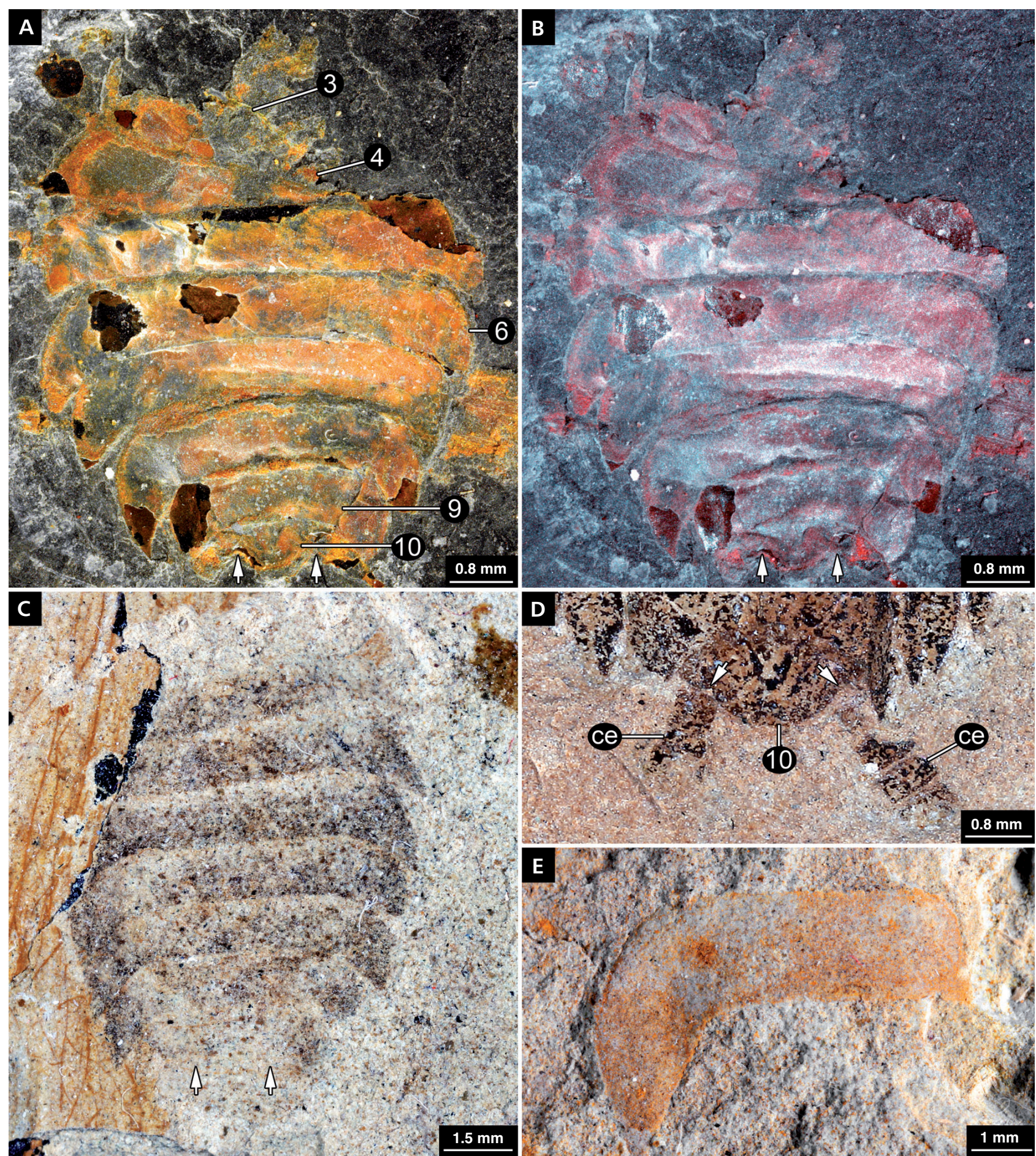

Figure 3. Larger instar of the blattoid nymphs from the Piesberg quarry and comparative specimens from Elmo and Mazon Creek. • A, B - MAS Pal 655. Best preserved specimen of the larger instar of the blattoid nymphs from the Piesberg quarry. Distinct notches are present in the tenth abdominal segment (arrows); A - under polarized light, B - under cyan-orange-macrofluorescence. • C - YPM IP 210164. Very similar appearing specimen from Elmo, also representing an isolated abdomen; arrows mark notches. $・$ D - YPM IP 027869. Detail of the posterior end of the abdomen of a blattoid nymph from Mazon Creek. The tenth abdominal segment has the same notches (arrows) as the specimens from the Piesberg quarry. These are the insertion areas of the cerci. • E - YPM IP 221049. An isolated left half of an abdominal tergite of a blattoid nymph from Elmo. Other abbreviation than before: ce - cercus. 
are larger, at least $3 \mathrm{~cm}$ estimated body size. There may also be a change in wing pad morphology in the larger specimens compared to the smaller ones if they are conspecific, but due to lack of knowledge we did not reconstruct such a morphological change.

\section{Discussion}

Without comparative material from Mazon Creek and Elmo the correct attribution of the specimens from the Piesberg quarry would not have been possible. The high similarity of the specimens from the Piesberg quarry to those of Mazon Creek and Elmo ( $c f$. Fig. 2) leaves no other interpretation than that the specimens from the Piesberg quarry are blattoid nymphs. Other superficially similar-appearing groups such as nymphal stages of Palaeodicytoptera can be ruled out. In the latter, the lateral extensions of the thoracic tergites (wing pads) are not continuous as in blattoids, but partly set off. Also other arthropod affinities are highly unlikely, such as arachnids, which would lack tergopleura-like extensions on the posterior body region (opisthosoma).

\section{Blattoid nymphs in the Palaeozoic}

Fossil blattoid nymphs from the Palaeozoic have been rarely investigated in the past, although blattoids appear to be a recurring element of Palaeozoic faunas. The most extensive body of work was presented by Sellards (1903, 1904a, b), who described different types of blattoid nymphs from Mazon Creek and Elmo locality, and ascribed them to five different species. This accurate work appears to have been ignored by subsequent authors (e.g., Rolfe 1967, Wootton 1972, Kukalová-Peck 1997, Garwood et al. 2012). Sellards' contributions are particular in that details of the ventral side, especially the appendages, are documented (e.g., Sellards 1904a, his figs 4, 8, 14).

Based on external morphology, the specimens from the Piesberg quarry resemble the specimens from Elmo as well as the specimens described by Sellards (1903, 1904a, b) and Kukalová-Peck (1997). The species ascriptions of Sellards $(1904 a, b)$ need to be re-evaluated as some of his interpretations of the nymphal specimens have been questioned (Handlirsch 1911) and the material from the Piesberg is more fragmentarily preserved than his material.

\section{Taphonomic remarks}

The specific fragmentation of the specimens from the Piesberg quarry, with a clear midline separating the right and left halfs of thoracic tergites, but also of abdominal ones, indicates that these specimens are exuviae. When moulting, the dorsal cuticle splits right at these preformed weak points. An interpretation as exuviae would also explain the displacement of some of the structures and the observed folding.

Concerning the preservation, the material from the Piesberg quarry appears very similar to the specimens from Elmo. Maybe most astonishing is the exuvial specimen from the Piesberg quarry with a single half of the metanotum still attached to the abdomen, which differs from a comparable specimen from Elmo only in size and the fact that the detached pronotum lies closely adjacent, but still clearly separated from it (Fig. 2A-C). This combination as well as a comparison with all the other specimens also strongly indicates that the specimens from the Piesberg represent exuviae, which have become partly or in some cases heavily disarticulated. This is quite different from specimens in Mazon Creek or Montceau-les-Mines, where some exuviae occur, but these are generally better articulated, and large parts of the material appears to be body fossils (C. Haug \& J.T. Haug, pers. obs.). There are more common features between the material from the Piesberg quarry and that from Elmo, for example the co-occurrence with similar and similarly preserved plant material. The high degree of fragmentation seen in the Elmo specimens gives a hint to how small pieces of a blattoid nymph could appear in the Piesberg quarry and how these pieces should look like. As some of the collectors at the Piesberg quarry are already highly trained in finding small and fragmented material, it should be possible to find more parts of blattoid nymphs in the near future.

Among the material from the Piesberg quarry is now the possibly smallest blattoid nymph specimen ever found in the Palaeozoic, with only 8-9 $\mathrm{mm}$ estimated body length. The smallest specimen that Sellards (1904a) reports was about one centimetre long. This might not seem much of a difference, but demonstrates that there is also preservation potential for even smaller nymphal specimens than those that have been known to date.

\section{Implications}

Despite the taxonomic uncertainty, the report of these nymphs is seen as a contribution to our knowledge on the ontogeny of Palaeozoic insects. Development of fossil arthropods in general is understudied (e.g., Haug, J.T. et al. $2011 b$ ), but yields the potential to provide significant insights into the phylogeny and evolution of a specific monophyletic group. A first step into such a palaeo-evo-devo approach is finding a sufficient amount of material. The material presented here is a further step forward in collecting enough material to reconstruct developmental sequences of different species within the blattoid lineage (Dictyoptera). 

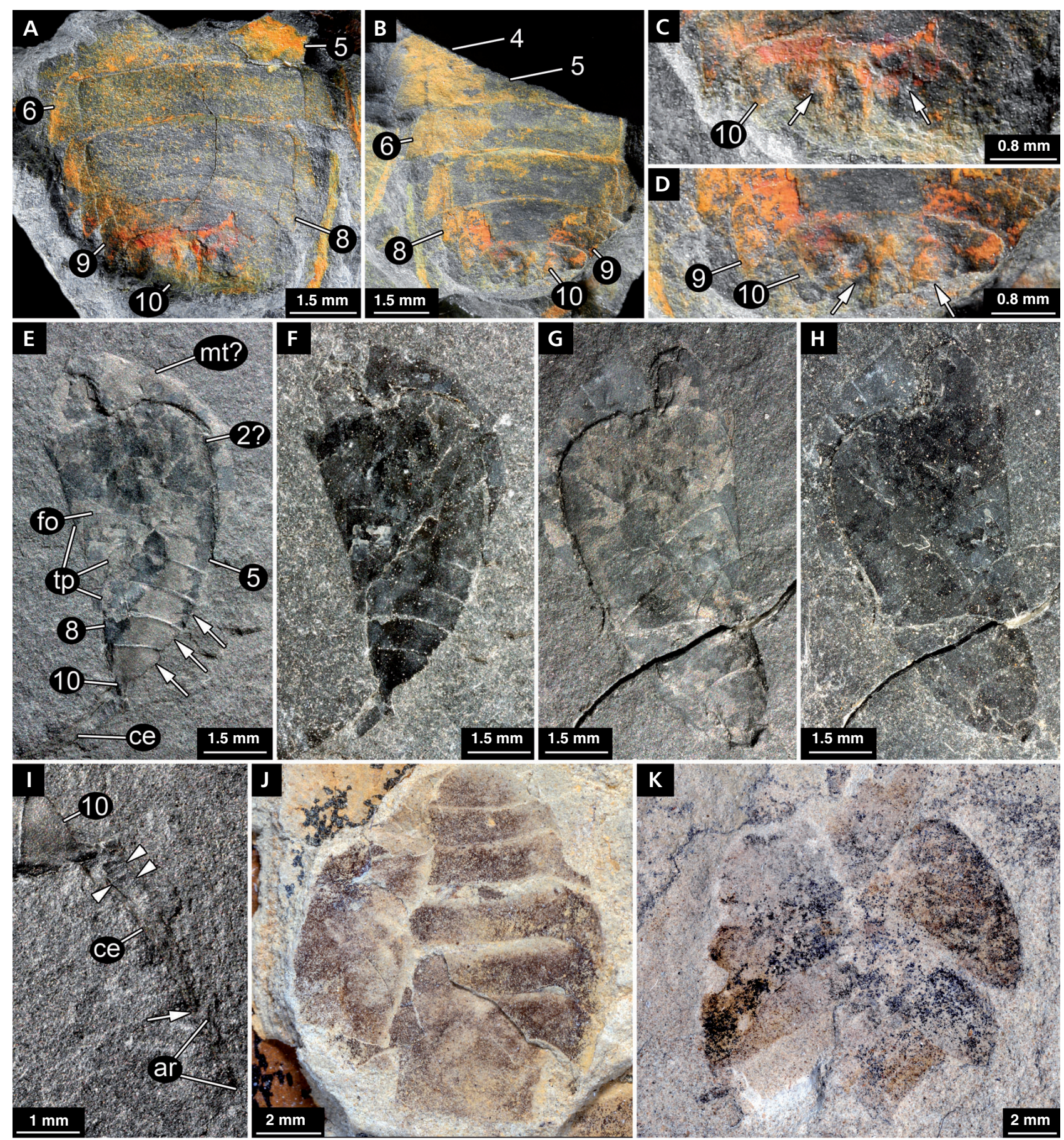

Figure 4. Larger instar of the blattoid nymphs from the Piesberg quarry and comparative specimens from Elmo. A-D, E, G, I under reflected light; F, H, J, K under polarized light. $\bullet$ A-I - specimens from the Piesberg quarry. A-D - MAS Pal 603; A, C - part; B, D -counterpart. $\bullet$ C, D - close-ups of the tenth abdominal segment with notches (marked by arrows). $\bullet$ E-I - MAS Pal 654; E, F, I - part, G, H - counterpart. E - the specimen is partly broken (marked by arrows), I-detail of cercus. Arrow heads mark annuli borders, arrow marks distal end. $\bullet \mathrm{J}, \mathrm{K}$ - comparative blattoid nymph specimens from Elmo, both also partly distorted and fragmented; J - YPM IP 221044, K - YPM IP 220990. Other abbreviations than before: 2? - possible second abdominal segment; ar - artefact due to shadow; fo - area of cuticle folded back on other parts of the specimen; mt? - possible metanotum; tp - tergo-pleura-like extensions.

The presentation of this material is also thought to bring such often small and unspectacular specimens to the attention of curators, but also of private collectors. The Piesberg is still actively excavated, and material from Elmo lies in different museum collections. Without the presentation provided here, additional material would most likely be overlooked, now the active search for more material can be started. 

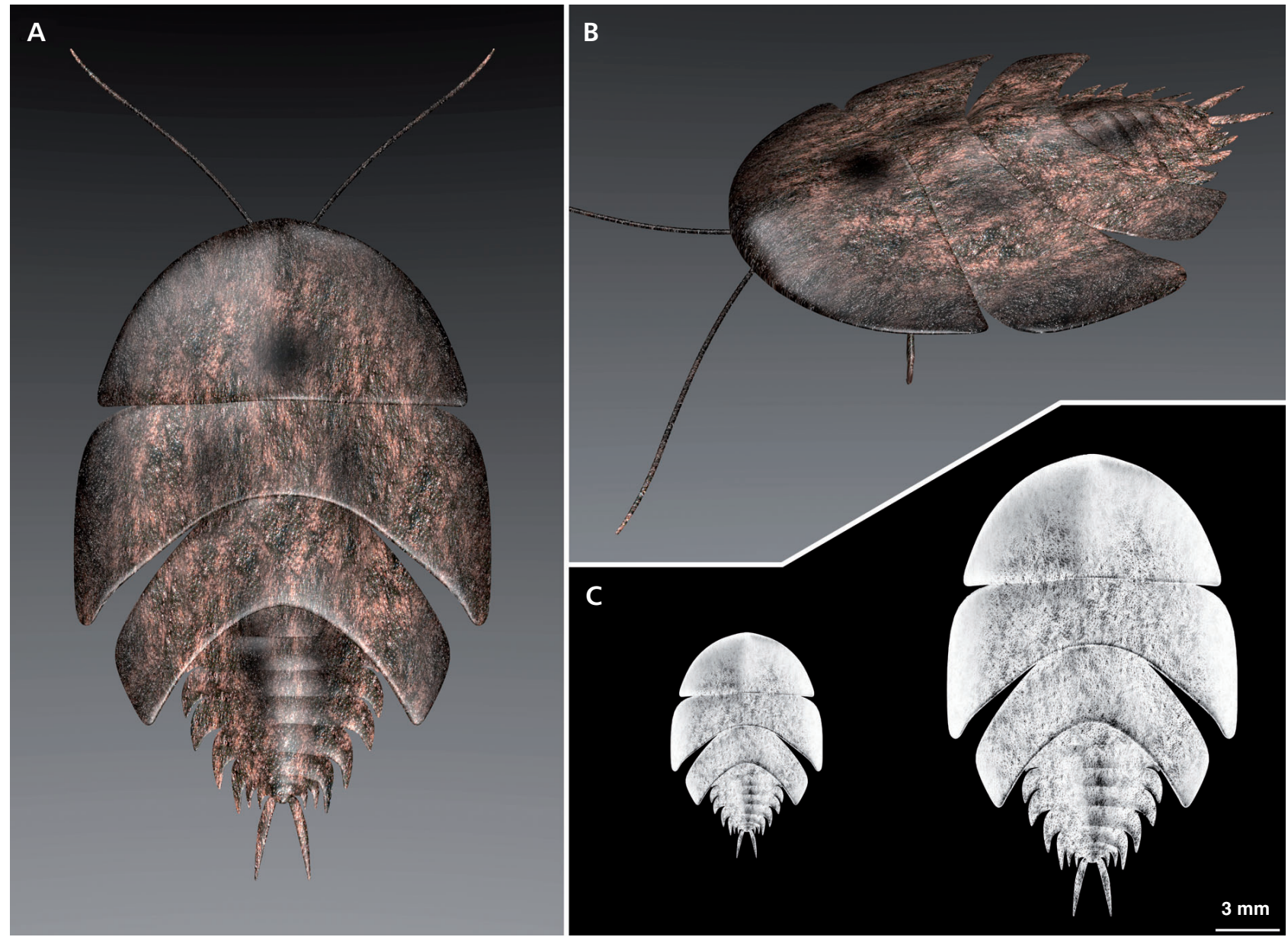

Figure 5. 3D model showing the principal morphology of the blattoid nymphs from the Piesberg quarry. Details missing in the specimens amended from comparative extant material (e.g., length of antennae), texture hypothetical, inspired by that of extant terrestrial arthropods. $\bullet$ A - dorsal view. - B - oblique antero-dorso-lateral view. $\bullet \mathrm{C}$ - size comparison of the smaller and the larger instar.

Besides the blattoid nymphs from the Piesberg quarry, Mazon Creek and Elmo, several possible candidates are known from the British coal measures (Bolton 1921-1922, Jarzembowski 1987). Further specimens appear to be present in the Montceau-les-Mines Lagerstätte (Garwood et al. 2012), where a large percentage of the insect fossils found there are nymphal stages (Burnham 1994), but mostly have not been in focus of a study involving developmental aspects.

Relatively complete developmental sequences of Palaeozoic insects are extremely rare (few examples in Kukalová-Peck 1997, Rasnitsyn \& Quicke 2002), and it is interesting to mention that none is known for a fossil blattoid, although numerous specimens of different developmental stages seem to be available. A precise knowledge of (relatively) early hemimetabolous insects is a requirement for reconstructing the evolution of holometaboly, the key innovation for the supposedly most successful monophyletic group of all (but see Introduction; see also Labandeira 2011 for the early evolution of holometaboly). Palaeozoic blattoid nymphs, as the here described forms, are often stated to resemble modern blattarian nymphs in overall morphology.

Another interesting structure of the here described blattoid nymphs is the wing pad. The wing pad of the small specimen (MAS Pal 653) is relatively large compared to its body size. In modern blattarian nymphs the wing pads are relatively short, the development of the wing taking place in late nymphal stages (e.g., Miall \& Denny 1886, Bell et al. 2007). This is the result of a condensation of the wing development. It parallels the evolutionary changes of ontogeny in the endopterygote lineage. In Palaeozoic blattoid nymphs the wing pads are in general longer than in extant blattarian nymphs. More specimens preserving wing pads and therefore allowing measurements will be important for clarifying this issue.

Alternatively, the long wing pad could indicate an advanced developmental stage and a small total size of a second species. Then the larger specimens would represent a different species. This possibility can be evaluated when more details on the adult blattoids are known. 


\section{Conclusion and outlook}

Different ontogenetic stages of another arthropod from the Piesberg quarry are known from one species of Euproops (Xiphosura; Schultka 2000) with no less then 10 successive stages, indicating a gradual morphological change throughout development (Haug, C. et al. 2012b). Additionally, we know different ontogenetic stages from Arthropleura and Aphantomartus pustulatus from the Piesberg quarry, but not to the same degree of detail as for Euproops, as fossils of the former two are much rarer and mostly incomplete (A. Leipner, pers. obs.). The blattoid nymphs presented here represent another example of preserved fossil ontogenetic information in the Piesberg quarry.

The presented case also shows that understanding incomplete fossils demands for comparisons with other, already better exploited Lagerstätten. For the Piesberg quarry, Elmo appears to be an important source for comparison.

As pointed out above, the Carboniferous is a crucial time for understanding the early diversification of insects and the evolution of their development. Insect fossils that exceed wing fragments are still rare from the Piesberg quarry. The blattoid nymphs described herein represent four additional specimens that fall into this better-preserved category. We also hope that the presentation of this material facilitates the identification of more such material for further studies.

\section{Acknowledgements}

Our acknowledgement for the permission to search for fossils in the Piesberg quarry goes to CEMEX Kies \& Splitt GmbH, Steinbruch Piesberg, Osnabrück, Germany. We thank the private collectors that spend a lot of their time in the Piesberg quarry. For the material investigated here we especially thank Michael Sowiak, Glandorf, who found specimen MAS Pal 653 and Pal 655, and Armin Dielforder, Münster, who found specimen MAS Pal 654. We are very grateful to Susan Butts and Jessica Utrup, Yale Peabody Museum, New Haven, who kindly made specimens available for comparative studies. Our thanks go to Dieter Waloszek and his work group Biosystematic Documentation, University of Ulm, for the possibility to use their imaging equipment. Carsten Brauckmann, University of Clausthal-Zellerfeld, Olivier Béthoux, National Museum of Natural History Paris, and Russell Garwood, University of Manchester, made helpful comments on the manuscript. We furthermore thank all people involved in programming freely available software that was used during this study, such as Gimp, Inkscape, OpenOffice, CombineZM, CombineZP, Image Analyzer, Microsoft Image Composite Editor, and Blender. JTH was kindly supported by Yale University and by the Alexander von Humboldt Foundation $(\mathrm{AvH})$ with a Feodor Lynen Research Fellowship for postdoctoral researchers and a return fellowship. $\mathrm{CH}$ was kindly supported by the German Academic Exchange Service (DAAD) with a return fellowship. Furthermore, JTH and $\mathrm{CH}$ want to express their thanks to their hosts Derek E.G. Briggs, Yale University and Yale Peabody Museum, and Steffen Harzsch, University of Greifswald, for their support.

\section{References}

Anderson, L.I. \& TREwin, N.H. 2003. An Early Devonian arthropod fauna from the Windyfield cherts, Aberdeenshire, Scotland. Palaeontology 46, 467-509.

DOI 10.1111/1475-4983.00308

BeCKemeYer, R.J. 2000. The Permian insect fossils of Elmo, Kansas. The Kansas School Naturalist 46, 1-16.

Bell, W.J., Roth, L.M. \& NalePA, C.A. 2007. Cockroaches Ecology, Behavior, and Natural History. 230 pp. The Johns Hopkins University Press, Baltimore.

Bengtson, S. 2000. Teasing fossils out of shales with cameras and computers. Palaeontologia Electronica 3(1), art. 4, 14 pp.

Béthoux, O. \& Herd, K.J. 2009. Discovery of an enigmatic and gigantic Pennsylvanian Archaeorthoptera. Journal of Orthoptera Research 18, 23-28. DOI 10.1665/034.018.0112

Bolton, H. 1921-1922. A Monograph of the Fossil Insects of the British Coal Measures. vi +156 pp. Palaeontographical Society, London.

Brauckmann, C. 1983. Ein Insektenrest (Odonata, Meganisoptera) aus dem Ober-Karbon des Piesberges bei Osnabrück. Osnabrücker naturwissenschaftliche Mitteilungen 10, 7-14.

BrauCKMANn, C. 1991. Ein neuer Insekten-Rest (Megasecoptera) aus dem Ober-Karbon von Osnabrück. Osnabrücker naturwissenschaftliche Mitteilungen 17, 25-32.

Brauckmann, C. 1995. Neue Insekten-Funde (Palaeodictyoptera: Breyeriida) aus dem Ober-Karbon von Osnabrück (Deutschland). Osnabrücker naturwissenschaftliche Mitteilungen 20/21, 157-165.

Brauckmann, C. \& Herd, K.J. 2000. Eine weitere neue Breyeriiden-Art (Insecta, Palaeodictyoptera) aus dem OberKarbon von Osnabrück (Deutschland). Neues Jahrbuch für Geologie und Paläontologie, Monatshefte 2000(6), 333-344.

Brauckmann, C. \& Herd, K.J. 2002. Insektenfunde aus dem Westfalium D (Ober-Karbon) des Piesberges bei Osnabrück (Deutschland), Teil 1 Palaeoptera. Osnabrücker naturwissenschaftliche Mitteilungen 28, 27-69.

Brauckmann, C. \& Herd, K.J. 2005. Insekten-Funde aus dem Westfalium D (Ober-Karbon) des Piesberges bei Osnabrück (Deutschland), Teil 2 Neoptera. Osnabrücker naturwissenschaftliche Mitteilungen 30/31, 19-65.

Brauckmann, C. \& Herd, K.J. 2007. A subcircular insect wing from the Late Carboniferous of Osnabrück, Germany. Clausthaler Geowissenschaften 6, 79-85.

Brauckmann, C., Herd, K.J. \& Leipner, A. 2009. InsektenFunde aus dem Westfalium D (Ober-Karbon) des Piesberges bei Osnabrück. Osnabrücker naturwissenschaftliche Mitteilungen 35, 5-30.

Braun, A. 1997. Vorkommen, Untersuchungsmethoden und Bedeutung tierischer Cuticulae in kohligen Sedimentgesteinen des Devons und Karbons. Palaeontographica, Abteilung B 245, 83-156. 
Briggs, D.E.G. 1979. Anomalocaris, the largest known Cambrian arthropod. Palaeontology 22, 631-664.

Briggs, D.E.G. \& Bartels, C. 2001. New arthropods from the Lower Devonian Hunsrück Slate (Lower Emsian, Rhenish Massif, western Germany). Palaeontology 44, 275-303. DOI 10.1111/1475-4983.00180

Briggs, D.E.G., Sutton, M.D., Siveter, David J. \& Siveter, Derek J. 2005. Metamorphosis in a Silurian barnacle. Proceedings of the Royal Society of London B 272, 2365-2369.

Budd, G.E. 2008. Head structure in upper stem-group euarthropods. Palaeontology 51, 561-573. DOI 10.1111/j.1475-4983.2008.00752.x

Burnham, L. 1994. The Stephanian (Late Carboniferous) insects of the basin of Montceau-les-Mines (Massif Central - France), 187-200. In Poplin, C. \& Heyler, D. (eds) Quand le Massif Central était sous l'Équateur: un écosystème carbonifère à Montceau-les-Mines. CTHS, Paris.

DALEY, A.C. \& BudD, G.E. 2010. New anomalocaridid appendages from the Burgess Shale, Canada. Palaeontology 53, 721-738. DOI 10.1111/j.1475-4983.2010.00955.x

Duncan, I.J., Titchener, F. \& Briggs, D.E.G. 2003. Decay and disarticulation of the cockroach: implications for preservation of the blattoids of Writhlington (Upper Carboniferous), UK. Palaios 18, 256-265.

DOI 10.1669/0883-1351(2003)018<0256:DADOTC >2.0.CO;2

Dunlop, J.A., Anderson, L.I., Kerp, H. \& Hass, H. 2004. A harvestman (Arachnida: Opiliones) from the Early Devonian Rhynie cherts, Aberdeenshire, Scotland. Transactions of the Royal Society of Edinburgh, Earth Sciences 94, 341-354.

Dunlop, J.A., Brauckmann, C. \& Steur, H. 2008. A Late Carboniferous fossil scorpion from the Piesberg, near Osnabrück, Germany. Fossil Record 11, 25-32. DOI 10.1002/mmng.200700010

FACTOR, D.F. \& Feldmann, R.M. 1985. Systematics and paleoecology of malacostracan arthropods in the Bear Gulch Limestone (Namurian) of central Montana. Annals of Carnegie Museum 54, 319-356.

FAYERS, S.R. \& TREwIN, N.H. 2003. A new crustacean from the Early Devonian Rhynie chert, Aberdeenshire, Scotland. Transactions of the Royal Society of Edinburgh: Earth Sciences 93, 355-382.

FAYERS, S.R. \& TREwin, N.H. 2005. A hexapod from the Early Devonian Windyfield chert, Rhynie, Scotland. Palaeontology 48, 1117-1130. DOI 10.1111/j.1475-4983.2005.00501.x

García-Bellido, D.C. \& Collins, D.H. 2006. A new study of Marrella splendens (Arthropoda, Marrellomorpha) from the Middle Cambrian Burgess Shale, British Columbia, Canada. Canadian Journal of Earth Sciences 43, 721-742. DOI 10.1139/e06-012

Garwood, R., Ross, A., Sotty, D., Chabard, D., Charbonnier, S., Sutton, M. \& Withers, P.J. 2012. Tomographic reconstruction of neopterous Carboniferous insect nymphs. PLoS ONE 7(9), e45779. DOI 10.1371/journal.pone.0045779

HandLIRSCH, A. 1911. New Paleozoic insects from the vicinity of Mazon Creek, Illinois. American Journal of Science (Series 4) 31, 297-326 + 353-377.

Haug, C., Haug, J.T., Fayers, S.R., Trewin, N.H., Castellani, C., WALOSZEK, D. \& MAAs, A. 2012a. Exceptionally preserved nauplius larvae from the Devonian Windyfield chert,
Aberdeenshire, Scotland. Palaeontologia Electronica 15, art. 15.2.24A.

Haug, C., Van Roy, P., Leipner, A., Funch, P., Rudkin, D.M., Schöllmann, L. \& HaUg, J.T. 2012b. A holomorph approach to xiphosuran evolution - a case study on the ontogeny of Euproops. Development Genes and Evolution 222, 253-268. DOI 10.1007/s00427-012-0407-7

Haug, J.T., Haug, C., Kutschera, V., Mayer, G., Maas, A., Liebau, S., Castellani, C., Wolfram, U., Clarkson, E.N.K. \& WaLoszeK, D. 2011a. Autofluorescence imaging, an excellent tool for comparative morphology. Journal of Microscopy 244, 259-272. DOI 10.1111/j.1365-2818.2011.03534.x

Haug, J.T., Haug, C., Maas, A., Kutschera, V. \& Waloszek, D. 2010. Evolution of mantis shrimps (Stomatopoda, Malacostraca) in the light of new Mesozoic fossils. BMC Evolutionary Biology 10, art. 290, $17 \mathrm{pp}$.

Haug, J.T., Haug, C., Waloszek, D. \& Schweigert, G. 2011 b. The importance of lithographic limestones for revealing ontogenies in fossil crustaceans. Swiss Journal of Geosciences 104, Supplement 1, S85-S98.

DOI 10.1007/s00015-010-0033-1

Hirst, S. 1923. On some arachnid remains from the Old Red Sandstone (Rhynie chert Bed, Aberdeenshire). Annals and Magazine of Natural History (Series 9) 12, 455-474.

Hughes, C.L. \& Kaufman, T.C. 2002. Hox genes and the evolution of the arthropod body plan. Evolution \& Development 4, 459-499. DOI 10.1046/j.1525-142X.2002.02034.x

JARZEMBOWSKI, E.A. 1987. The occurrence and diversity of Coal Measure insects. Journal of the Geological Society 144, 507-511. DOI 10.1144/gsjgs.144.3.0507

KÜHL, G., Bergström, J. \& RUST, J. 2008. Morphology, palaeobiology and phylogenetic position of Vachonisia rogeri (Arthropoda) from the Lower Devonian Hunsrück Slate (Germany). Palaeontographica, Abteilung A 286, 123-157.

KuKalovÁ-PeCK, J. 1997. Mazon Creek insect fossils: the origin of insect wings and clues about the origin of insect metamorphosis, 194-207. In Shabica, C.W. \& Hay, A.A. (eds) Richardson's Guide to the Fossil Fauna of Mazon Creek. Northeastern Illinois University Press, Chicago.

LABANDEIRA, C.C. 2011. Evidence for an earliest Late Carboniferous divergence time and the early larval ecology and diversification of major Holometabola lineages. Entomologica Americana 117, 9-21. DOI 10.1664/10-RA-011.1

Maas, A., Waloszek, D., Chen, J.-Y., Braun, A., Wang, X.-G. \& HuANG, D.-Y. 2004. Phylogeny and life habits of early arthropods - predation in the Early Cambrian sea. Progress in Natural Science 14, 158-166. DOI 10.1080/10020070412331343301

MeEK, F.B. \& Worthen, A.H. 1868. Preliminary notice of a scorpion, a Eurypterus? and other fossils from the Coal Measures of Illinois and Iowa. American Journal of Science and Arts 45, 25.

Miall, L.C. \& Denny, A. 1886. The Structure and life-history of the cockroach (Periplaneta orientalis). 224 pp. Lovelle Reeve \& Co., London. DOI 10.5962/bhl.title.48436

Poplin, C. \& HeYler, D. 1994. Quand le Massif Central était sous l'Équateur: un écosystème carbonifère à Montceau-lesMines. CTHS, Paris.

Racheboeuf, P.R., Schram, F.R. \& Vidal, M. 2009. New mala- 
costracan Crustacea from the Carboniferous (Stephanian) Lagerstätte of Montceau-les-Mines, France. Journal of Paleontology 83, 624-629. DOI 10.1666/08-171R.1

Racheboeuf, P.R., Vannier, J. \& Anderson, L.I. 2002. A new three-dimensionally preserved xiphosuran chelicerate from the Montceau-les-Mines Lagerstätte (Carboniferous, France). Palaeontology 45, 125-147. DOI 10.1111/1475-4983.00230

Racheboeuf, P.R., Vannier, J., Schram, F.R., Chabard, D. \& SotTy, D. 2008. The euthycarcinoid arthropods from Montceau-les-Mines, France: functional morphology and affinities. Earth and Environmental Science Transactions of the Royal Society of Edinburgh 99, 11-25.

DOI $10.1017 /$ S1755691008006130

RASNITSYN, A.P. \& QUICKE, D.L.J. 2002. History of Insects. xii + 517 pp. Kluwer Academic Publishers, Dordrecht, Boston, London.

RÖßLER, R. 1998. Arachniden-Neufunde im mitteleuropäischen Unterkarbon bis Perm - Beitrag zur Revision der Familie Aphantomartidae Petrunkevitch 1945 (Arachnida, Trigonotarbida). Paläontologische Zeitschrift 72, 67-88.

Rolfe, W.D.I. 1967. Rochdalia, a Carboniferous insect nymph. Palaeontology 10, 307-313.

SANTINI, F. \& TYLER, J.C. 2004. The importance of even highly incomplete fossil taxa in reconstructing the phylogenetic relationships of the Tetraodontiformes (Acanthomorpha: Pisces). Integrative and Comparative Biology 44, 349-357. DOI 10.1093/icb/44.5.349

SCHNeIDER, J. 1983. Die Blattodea (Insecta) des Paläozoikums. Teil 1: Systematik, Ökologie und Biostratigraphie. Freiberger Forschungshefte C 382, 106-145.

SCHNeIDER, J. 1984. Die Blattodea (Insecta) des Paläozoikums. Teil II: Morphogenese der Flügelstrukturen und Phylogenie. Freiberger Forschungshefte C 391, 5-34.

Scholtz, G. \& Edgecombe, G.D. 2006. The evolution of arthropod heads: reconciling morphological, developmental and palaeontological evidence. Development Genes \& Evolution 216, 395-415. DOI 10.1007/s00427-006-0085-4

SCHRAm, F.R. \& Horner, J. 1978. Crustacea of the Mississippian Bear Gulch Limestone of Central Montana. Journal of Paleontology 52, 394-406.

Schram, F.R., Boere, A.C. \& Thomas, N. 2006. Cycloidea of the Mississippian Bear Gulch Limestone of Central Montana. Contributions in Science 504, 1-8.

SchultKA, S. 2000. Zur Palökologie der Euproopiden im Nordwestdeutschen Oberkarbon. Mitteilungen aus dem Museum für Naturkunde in Berlin, Geowissenschaftliche Reihe 3, 87-98.

SCOURFIELD, D.J. 1926. On a new type of crustacean from the Old Red Sandstone (Rhynie Chert Bed, Aberdeenshire) - Lepidocaris rhyniensis, gen. et sp. nov. Philosophical Transactions of the Royal Society of London B 214, 153-187 + 3 pls.

SCOURFIELD, D.J. 1940. Two new and nearly complete specimens of young stages of the Devonian fossil crustacean Lepidocaris rhyniensis. Proceedings of the Linnean Society 152, 290-298. DOI 10.1111/j.1095-8312.1940.tb00265.x

SCUDDER, S.A. 1884. A contribution to our knowledge of Palaeozoic Arachnida. Proceedings of the American Academy of Arts and Sciences 20, 15-22. DOI 10.2307/25138764

Sellards, E.H. 1903. Some new structural characters of Paleozoic cockroaches. American Journal of Science (Series 4) 15, $307-315+2 \mathrm{pl}$.

Sellards, E.H. 1904a. A study of the structure of Paleozoic cockroaches, with descriptions of new forms from the Coal Measures. American Journal of Science (Series 4) 18, 113-134.

Sellards, E.H. 1904b. A study of the structure of Paleozoic cockroaches, with descriptions of new forms from the Coal Measures. American Journal of Science (Series 4) 18, 213-227.

Shabica, C.W. \& Hay, A.A. 1997. Richardson's Guide to the Fossil Fauna of Mazon Creek. 308 pp. Northeastern Illinois University Press, Chicago.

Stockmeyer Lofgren, A., Plotnick, R.E. \& Wagner, P.J. 2003. Morphological diversity of Carboniferous arthropods and insights on disparity patterns through the Phanerozoic. Paleobiology 29(3), 349-368.

DOI 10.1666/0094-8373(2003)029<0349:MDOCAA>2.0.CO;2

Van Roy, P., Orr, P.J., Botting, J.P., Muir, L.A., Vinther, J., Lefebvre, B., el Hariri, K. \& Briggs, D.E.G. 2010. Ordovician faunas of Burgess Shale type. Nature 465, 215-218. DOI 10.1038/nature09038

Van Roy, P. \& Tetlie, O.E. 2006. A spinose appendage fragment of a problematic arthropod from the Early Ordovician of Morocco. Acta Palaeontologica Polonica 51, 239-246.

WalosseK, D. \& MülleR, K.J. 1998. Cambrian 'Orsten'-type arthropods and the phylogeny of Crustacea, 139-153. In ForTeY, R.A. \& THOMAs, R.H. (eds) Arthropod relationships. Systematics Association Special Volume Series 55. Chapman \& Hall, London.

Waloszek, D., Chen, J., MAAs, A. \& WANG, X. 2005. Early Cambrian arthropods - new insights into arthropod head and structural evolution. Arthropod Structure \& Development 34, 189-205. DOI 10.1016/j.asd.2005.01.005

Waloszek, D., MaAs, A., Chen, J. \& Stein, M. 2007. Evolution of cephalic feeding structures and the phylogeny of Arthropoda. Palaeogeography, Palaeoclimatology, Palaeoecology 254, 273-287. DOI 10.1016/j.palaeo.2007.03.027

Wootton, R.J. 1972. Nymphs of Palaeodictyoptera (Insecta) from the Westphalian of England. Palaeontology 15, $662-675$.

Zessin, W. 2006. Zwei neue Insektenreste (Megasecoptera, Odonatoptera) aus dem Westfalium D (Oberkarbon) des Piesberges bei Osnabrück, Deutschland. Virgo, Mitteilungsblatt des Entomologischen Vereins Mecklenburg 9(1), 37-45.

Zessin, W. 2008. Überblick über die paläozoischen Libellen (Insecta, Odonatoptera). Virgo, Mitteilungsblatt des Entomologischen Vereins Mecklenburg 11(1), 5-32. 